\title{
PERBEDAAN HASIL BELAJAR DAN AKTIVITAS SISWA DENGAN MENGGUNAKAN MODEL PEMBELAJARAN PREDICT-OBSERVE-EXPLAIN (POE) DAN MODEL DIRECT INSTRUCTION
}

\author{
Jamanat Artinus Banjarnahor ${ }^{*}$ dan Melva Silitonga \\ Program Studi Pendidikan Biologi, FMIPA, Universitas Negeri Medan, Jl. Willem Iskandar Psr. V, Medan Estate, \\ Medan, Indonesia, 20221 \\ *E-mail : manatbanjarnahor@gmail.com
}

\begin{abstract}
ABSTRAK
Penelitian ini bertujuan untuk mengetahui perbedaan hasil belajar dan aktivitas siswa dengan menggunakan model pembelajaran Predict Observe Explain (POE) dan Direct Instruction (DI) pada materi sistem peredaran darah manusia di kelas XI IPA SMA Negeri 14 Medan Tahun Pembelajaran 2017/2018 serta melihat perbedaan pada kedua model tersebut. Jenis penelitian adalah eksperimen semu. Sampel penelitian yaitu kelas XI IPA 4 sebagai kelas POE dan kelas XI IPA 3 sebagai kelas DI. Alat pengumpul data hasil belajar yaitu soal berbentuk pilihan ganda sebanyak 20 soal sedangkan untuk mendapatkan data aktivitas siswa diamati dengan menggunakan lembar observasi. Tes dilakukan diakhir pembelajaran sedangkan aktivitas siswa diamati selama pembelajaran. Data yang diperoleh di analisis dengan uji t. Hasil penelitian menunjukkan rata-rata hasil belajar siswa pada sistem peredaran darah manusia menggunakan Model pembelajaran Predict Observe Explain (POE) yaitu $(76,95 \pm 10,83)$ dan model pembelajaran Direct Instruction (DI) $(73,12 \pm 8,50$ ) yaitu berbeda secara signifikan pada taraf $\alpha=0,05$. Hasil penelitian juga menunjukkan bahwa ada perbedaan antara aktivitas belajar siswa yang dibelajarkan dengan menggunakan model pembelajaran POE dan DI dengan rata rata 70,6 untuk kelas POE dan 50,3 untuk kelas DI. Data analisis menunjukkan bahwa hasil belajar dan aktivitas siswa yang menggunakan model pembelajaran POE lebih baik daripada model DI untuk materi Sistem Peredaran Darah Manusia di kelas XI IPA SMA Negeri 14 Medan T.P 2017/2018.
\end{abstract}

Kata kunci: Model pembelajaran Predict Observe Explain (POE), model pembelajaran Direct Instruction (DI), hasil belajar, aktifitas siswa

\section{ABSTRACT}

This study aims to obtain differ on student achievement and activities by using Predict Observe Explain (POE) and Direct Instruction (DI) learning models on human circulatory system material in class XI IPA SMA Negeri 14 Medan Learning Year 2017/2018 and to see the difference in both models. This type of research is a quasi experiment. The research sample is class XI IPA 4 as POE class and class XI IPA 3 as DI class. The data collection tool of learning result is the question of multiple choice form as much as 20 problems while to get student activity data observed by using observation sheet. The test is done at the end of the learning while the student activity is observed during the learning. Data obtained in the analysis by $t$ test. The result of data analysis showed the average of student achievement in human circulation system using Predict Observe Explain (POE) learning model is $(76,95 \pm 10,83)$ and Direct Instruction (DI) learning model $(73,12 \pm 8,50)$ differ significantly at $\alpha=0.05$. The results also showed that there is a difference between learning activities learned by using POE and DI learning models with an average of 70.6 for POE and 50.3 for DI class. The data analysis show that students achievement and activities using the POE learning model better than the DI model for the Human Circulatory System in the class XI IPA SMA Negeri 14 Medan T.P 2017/2018.

Keywords :Predict Observe Explain (POE) learning model type, Direct Instruction (DI) learning model type, student achievement, student activity.

\section{PENDAHULUAN}

Agar siswa aktif dalam pembelajaran maka harus dipilih model metode pendekatan dan media yang tepat sesuai materi pembelajaran sebab dengan aktivitas siswa yang baik mereka akan termotivasi untuk lebih memahami materi pembelajaran sehingga hasil belajar juga menjadi lebih baik. Selain itu, proses pembelajaran akan lebih variatif, inovatif, dan konstruktif dalam merekonstruksi wawasan pengetahuan dan implementasinya sehingga dapat meningkatkan aktivitas dan kreativitas peserta didik. Trianto (2009) mengemukakan bahwa "setiap model pembelajaran mengarahkan kita ke dalam mendesain pembelajaran untuk membantu peserta didik sedemikian rupa sehingga tujuan pembelajaran tercapai". Model pembelajaran yang digunakan dalam kegiatan pembelajaran bukan hanya disesuaikan dengan tujuan yang hendak dicapai tetapi disesuaikan pula dengan bahan atau 
materi pembelajaran serta karakteristik dan kebutuhan siswa. Hasil observasi di kelas ketika proses belajar mengajar berlangsung. Siswa cenderung pasif, malas, dan kurang disiplin. Pada kondisi ini diperlukan alternatif strategi lain untuk mengatasinya. Seperti yang disarankan oleh Yip (1998), guru harus menggunakan model pembelajaran konstruktivis untuk meningkatkan pembelajaran konseptual dan meninggalkan model pengajaran tradisional yang menekankan transfer langsung pengetahuan.

Pada bulan Maret 2017 peneliti melaksanakan observasi dan wawancara di SMA Negeri 14 Medan. Berdasarkan hasil wawancara dengan guru mata pelajaran biologi kelas XI IPA bahwa pembelajaran biologi dilaksanakan dengan metode diskusi dan ceramah. Penggunaan model pembelajaran yang lebih bervariasi belum diterapkan. Dijelaskan juga bahwa KKM untuk mata pelajaran Biologi adalah 75. Mengenai aktivitas belajar siswa cenderung pasif dalam proses pembelajaran berlangsung.

Hal itu disebabkan oleh pemilihan model pembelajaran yang kurang bervariasi. Salah satu pembelajaran ekspositori atau disebut juga dengan pembelajaran whole class teaching dimana guru menerangkan dan siswa hanya mendengar dan mencatat sehingga tidak terlihat interaksi antar siswa didalam kelas yang membuat kondisi kelas dimana siswanya bersifat individual dan kurangnya aktivitas yang terlihat pada siswa diakibatkan oleh aktivitas guru mendominasi pada proses pembelajaran tersebut, namun ini bukan kesalahan dari guru itu sendiri, melainkan karena keterbatasan waktu dan sumber daya yang menjadi penyebab utamanya.

Model pembelajaran POE (PredictObserve-Explain) merupakan suatu strategi yang efisien untuk menciptakan diskusi para siswa mengenai konsep ilmu pengetahuan. Model pembelajaran POE melibatkan siswa dalam meramalkan suatu fenomena, melakukan observasi melalui demonstrasi atau eksperimen, dan akhirnya menjelaskan hasil demonstrasi dan ramalan mereka sebelumnya (Indrawati \& Setiawan, 2009). Kemampuan POE dapat menyelidiki gagasan siswa dan cara mereka dalam menerapkan pengetahuan pada keadaan yang sebenarnya (praktikum). Pembelajaran ini memungkinkan siswa berpindah atau bergerak dan bekerja atau belajar, serta memberikan kesempatan kepada siswa untuk terlibat langsung dalam pembelajaran. Kesiapan guru untuk mengenal karakteristik siswa dalam pembelajaran merupakan modal utama penyampaian bahan belajar dan menjadi indikator suksesnya pelaksanaan pembelajaran.
POE adalah salah satu strategi pembelajaran yang memungkinkan siswa untuk mempelajari konsep-konsep sains menggunakan mengajar konstruktivis dengan mengaitkan pengetahuan peserta didik sebelumnya dengan informasi baru (Bilen \& Kose, 2010). Penelitian yang dilakukan oleh Wu dan Chin Chung (2005) juga menunjukkan bahwa penggunaan POE sebagai salah satu yang berdasarkan konstruktivisme dapat meningkatkan hasil belajar biologi. POE dapat membantu siswa mengeksplorasi dan meneguhkan gagasannya, khususnya pada tahap prediksi dan pemberian alasan. POE terdapat beberapa metode saintifik yang merupakan bagian dari pembelajaran sains yaitu, membuat hipotesis (predict), melakukan eksperimen (observe) dan melakukan analisis (explain). Metode saintifik lainnya yaitu mendefinisikan dan mengambil kesimpulan. POE seringkali disebut strategi pembelajaran dimana guru menggali pemahaman siswa dengan cara meminta mereka untuk melaksanakan tiga tugas utama, yaitu prediksi (predict), observasi (observe), dan memberikan penjelasan (explain). Tahap-tahap POE dapat diuraikan sebagai berikutyaitu (1) Terlebih dahulu siswa diajak untuk memprediksi apa yang akan terjadi, mereka tidak diperkenankan untuk melakukan observasi secara mendetail (2) menuliskan apa yang memotivasi prediksi mereka untuk mengetahui jawabannyadan (3) menanyakan kepada siswa alasan prediksi berdasarkan teori yang mereka sampaikan. Dari karakterisitik model itu, POE cocok diterapkan dalam pembelajaran biologi SMA. Selain itu peneliti berharap dapat sedikit membantu dalam memecahkan masalah dengan melakukan penelitian menggunakan strategi POE (Prediction, Observation and Explanation)

Model pembelajaran (DI) langsung adalah salah satu model pembelajaran yang masih berlaku dan sangat diterapkan oleh guru-guru. Alasan guru menggunakan model ini antara lain praktis dan dapat menyampaikan informasi dengan cepat. Djamarah (2010) mengatakan bahwa model pembelajaran langsung adalah model tradisional atau disebut juga dengan metode ceramah, karna sejak dulu model ini diterapkan guru dalam berkomunikasi lisan dengan siswa dalam proses belajar. Dalam pembelajaran model langsung ditandai dengan ceramah yang diiringi dengan penjelasan, serta pembagian tugas dan latihan. Karena karakteristik Model DI lebih menekankan peran guru maka model ini akan menekan keingintahuan dan keaktifan siswa, siswa akan lebih cepat bosan dengan pembelajaran.Sehingga model ini seharusnya tidak harus sering digunakan dalam pembelajaran. Tapi disamping sisi negatif dari model pembelajaran ini, model DI mempunyai 


\begin{tabular}{cc}
\hline \multicolumn{2}{c}{ Hasil Belajar POE } \\
\hline Nilai & Frekuensi \\
\hline 90 & 4 \\
85 & 2 \\
80 & 19 \\
75 & 6 \\
70 & 5 \\
65 & 2 \\
60 & 2 \\
55 & 1 \\
Jumlah & 3155 \\
Rata rata & 76,95 \\
Standar Deviasi & 10,83 \\
Varians & 117,28 \\
\hline
\end{tabular}

kelebihan yaitu memungkinkan menyampaikan pembelajaran secara terstruktur dan terarah.

\section{METODE PENELITIAN}

Penelitian dilaksanakan pada bulan Oktober-Desember 2017 di SMA Negeri 14 Medan . Populasi pada penelitian adalah seluruh siswa SMA Negeri 14 Medan yang berjumlah 245 orang. Sampel yang digunakan dalam penelitian adalah kelas XI IPA 3 dan XI IPA 4 denngan teknik Random Sampling.

Jenis pelitian ini adalah penelitian quasi eksperimen dimana penelitian ini melibatkan dua sampel yaitu kelas XI IPA 4 sebagai kelas eksperimen yang menggunakan model Predict Observe Explain (POE) dan Kelas XI IPA 3 sebagai kelas eksperimen pembeda yang diberi perlakuan Direct Instruction (DI) dengan menerapkan metode ceramah-diskusi dalam penelitiannya. Bentuk desain quasi-experimental yang digunakan adalah non-equivalent groups pretest-posttest desain. Dalam desain ini kelompok eksperimen 1 maupun kelompok eksperimen 2 dipilih secara purposive.

Instrumen penelitian ini yaitu Test dan lembar observasi. Hasil beljar akan diukur dengan menggunakan test sedangkan aktivitas siswa diukur dengan lembar observasi yang akan diisi oleh observer. Jenis penelitian ini adalah quasi eksperimen. Teknik analisis data yang dilakukan dengan $u j i t$

\section{HASIL PENELITIAN}

\section{Hasil Belajar Kelas Predict-Observe-Explain (POE)}

Dalam nilai postest yang didapatkan dapat dilihat bahwa rata rata nilai yang didapat sudah termasuk baik dengan rata rata nilai 76,95. Dari data yang didapat sebagian besar sudah mendapat nilai yang sangat bagus yaitu direntang 80-90 sebanyak 25 orang, dapat dilihat pada tabel berikut.
Tabel 1. Hasil Belajar Kelas POE

\section{Hasil Belajar Kelas Direct Instruction (DI)}

Berdasarkan data yang diperoleh dari hasil penelitian, dapat dilihat pada tabel berikut.

Tabel 2. Hasil Belajar Kelas Direct Instruction

\begin{tabular}{cc}
\hline \multicolumn{2}{c}{ Hasil Belajar DI } \\
\hline Nilai & Frekuensi \\
\hline 90 & 2 \\
85 & 5 \\
80 & 8 \\
75 & 13 \\
70 & 5 \\
65 & 4 \\
60 & 2 \\
55 & 1 \\
Jumlah & 3005 \\
Rata rata & 73,12 \\
Standar Deviasi & 8,50 \\
Varians & 72,25 \\
\hline
\end{tabular}

Berdasarkan Tabel 2. di atas diperoleh nilai hasil belajar postest sebanyak 73,12 tergolong baik namun jumlah siswa yang mendapat nilai bagus di kisaran $80-90$ adalah sebanyak 15 . Nilai tertinggi 90 dengan frekuensi 2 dan nilai terendah 55 dengan frekuensi 1.

\section{Aktivitas Belajar Kelas POE dan Kelas DI}

Data Aktivitas Belajar dapat dilihat pada tabel dibawah ini.

Tabel 3. Aktivitas belajar siswa

\begin{tabular}{lcc}
\multicolumn{1}{c}{ Aspek } & Skor POE & Skor DI \\
\hline Mengemukakan Fakta & 62,5 & 37,5 \\
Mengajukan Pertanyaan & 70 & 47,5 \\
Mengemukakan Pendapat & 67,5 & 35 \\
Diskusi & 80 & 65 \\
Melihat Gambar & 72,5 & 57,5 \\
Mengamati Eksperimen & 67,5 & 40 \\
Mengerjakan tes & 67,5 & 67,5 \\
\hline
\end{tabular}

Pada data diatas menunjukkan bahwa aktivitas belajar pada siswa di kelas POE > DI yaitu 70,68 $>50,33$ berarti aktivitas yang terjadi di kelas POE lebih aktif dibanding dengan kelas DI. Pada Aspek yang diamati juga terdapat perbedaan yang signifikan yaitu pada hampir semua aspek dimana pada kelas DI lebih sedikit aktivitas yang terjadi selama proses pembelajaran 


\section{PEMBAHASAN}

Setelah diberikan perlakuan model pembelajaran yang berbeda terhadap kedua kelas sampel, maka diberikan postes dan diperoleh nilai rata-rata hasil belajar siswa meningkat. Hasil belajar tersebut menunjukan bahwa nilai rata-rata hasil belajarkelas yang dibelajarkan dengan model POE pada kelas eksperimen XI IPA 4 lebih tinggi yaitu 76,95 dibandingkan nilai rata-rata hasil belajar model pembelajaran DI pada kelas eksperimen kedua yaitu XI IPA 3 yaitu 73,12. Untuk mengetahui ada tidaknya perbedaan antara hasil belajar siswa kelas Predit Observe Explain (POE) denganDirect Instruction (DI), maka dilakukan pengujian hipotesis dengan menggunakan uji $t$ pada taraf signifikan 0,05 . Secara statistik pada data hasil belajar diperoleh $t_{\text {hitung }}=2,18$ dan $t_{\text {tabel }}=1,9938$, hal ini menunjukan bahwa nilai rata-rata hasil belajarkedua kelas ada perbedaan antara model pembelajaran Predict Observe Explain (POE) dengan model pembelajaran Direct Instruction (DI). Pada Aktivitas siswa kelas POE > DI yaitu 70,68 > 50,33 menunjukkan adanya perbedaan aktivitas di kedua kelas tersebut

Hasil penelitian ini menunjukkan bahwa hasil belajar siswa pada pembelajaran sistem peredaran darah manusia dengan model pembelajaran Predict Observe Explain lebih baik dibandingkan dengan model pembelajaran Direct Instruction hal tersebut terlihat dari hasil belajar yang didapat selama penelitian. Pada model POE kelompok mampu menguasai materi pembelajaran baik secara pribadi maupun setelah berbagi dengan teman kelompok. Hal ini mampu mengacu siswa untuk mengutarakan pendapatnya dan siswa lebih aktif. Setelah menyatukan pemikiran dalam kelompok kemudian kelompok-kelompok berbagi kepada keseluruh kelas apa yang telah mereka diskusikan. Sedangkan pada kelas dengan model pembelajaran Direct Instruction (DI) siswa sulit untuk berkonsentrasi sehingga kurang menyerapi makna pembelajaran yang disampaikan. Hal ini terjadi karena pada pembelajaran di kelas DI lebih terpusat pada guru sehingga murid terkesan bosan saat pembelajaran berlangsung.

Hal diatas juga didukung oleh penelitian Udayani, dkk (2016) mengenai penerapan Model POE untuk meningkatkan hasil belajar menujukkan bahwa pembelajaran model POE ini dapat meningkatkan hasil belajar dari siswa. Pembelajaran POE dapat membantu pemahaman secara konstruktivistik sehingga mereka dapat mengingat lebih lama konsep yang telah diperoleh selama pembelajaran berlangsung. Dalam penelitian Firdos (2013) tentang pengaruh pembelajaran POE juga terhadap hasil belajar membuktikan bahwa siswa cenderung lebih aktif dan mempunyai hasil belajar yang signifikan dibanding dengan kelas tradisional. Sehingga POE dapat membangun pembelajaran yang lebih aktif untuk siswa. Melalui pengamatan langsung pada kedua kelas siswa lebih aktif di kelas POE dibanding DI, terutama saat diskusi sedang dilakukan. Dari sintaks Model POE siswa lebih aktif di tahap predict dan observenya. Pada tahap itu siswa aktif mengemukakan pendapatnya dan fakta yang diketahuinya serta di kegiatan diskusi yang berlangsung. Pada tahap ini sebagian siswa masih agak sulit mengutarakan pendapat dan fakta yang diketahuinya untuk tapi sebagian siswa lagi mereka sudah antusias mengemukannya. Namun dibalik antusias siswa ada kendala yaitu di tahap observe yaitu melakukan pengamatan dan eksperimen pada saat pengamatan dan eksperimen siswa membutuhkan bimbingan guru tapi karena tidak semua siswa bisa ditangani maka suasana kelas jadi agak kacau. Hal ini diungkapkan oleh penelitian Puspitasari,dkk (2015) tentang penerapan model POE terhadap ketereampilan kerja ilmiah dan hasil belajar bahwa penggunaan model POE ini membutuhkan waktu dan persiapan yang lama untuk penerapannya dan jika segala faktor yang dibutuhkan sudah dilaksanakan maka tujuan pembelajaran juga akan tercapai

Pada siswa kelas DI karena pembelajaran lebih terpusat pada guru maka pembelajaran cenderung membosankan dan siswa jarang mengemukakan pendapatnya terhadap suatu masalah. Memang ada tahap diskusi yang dilakukan oleh siswa agar siswa bisa aktif dalam pembelajaran namun karena setiap karakter siswa berbeda maka mereka cederung kurang aktif dalam berdiskusi dibanding dengan kelas POE Namun jika penggunaan Model pembelajaran langsung diterapkan secara baik dan benar dan dikombinasikan model ini pasti bisa meningkatkan hasil belajar serta aktivitas siswa seperti yang di teliti oleh Suharti, dkk (2016) mengenai penerapan Model Pembelajaran langsung terhadap mata pelajaran matematika yang mengatakan bahwa jika penggunaan model pembelajaran dilakukan dengan baik dan dikombinasikan dengan metode lain maka akan meningkatkan hasil belajar siswa maupun aktivitas siswa tersebut.

Model pembelajaran POE jauh lebih baik jika dibandingkan dengan model pembelajaran DI tersebut terlihat dari keaktifan siswa memecahkan masalah menyangkut sistem peredaran darah manusia. Pada model POE kelompok mampu menguasai masalah materi pembelajaran baik secara pribadi maupun setelah berbagi dengan teman kelompok serta dapat mengungkapkan fakta dan pendapatnya lebih bebas daripada kelas DI. 
Setelah menyatukan pemikiran dalam kelompok kemudian kelompok berbagi kepada keseluruh kelas apa yang telah mereka diskusikan dan apa yang didapat dari pengamatan dalam kegiatan pembelajaran. Sedangkan pada kelas dengan model pembelajaran DI siswa sulit untuk berkonsentrasi sehingga kurang menyerapi makna pembelajaran yang disampaikan. Kelas juga kelihatan kurang aktif dalam kegiatan pembelajaran terlihat dari pengamatan yang sudah dilakukan. Hal ini disebabkan oleh minimnya partisipasi siswa dalam pembelajaran dengan menggunakan model ini, karena sifat dari model DI itu mengutamakan peran guru dalam pembelajaran sehingga siswa kelihatan pasif dan guru cenderung yang aktif.

\section{KESIMPULAN}

Hasil belajar dan aktivitas belajar siswa yang dibelajarkan menggunakan model pembelajaran Predict Observe Explain (POE) pada materi sistem peredaran darah manusia di kelas XIIPA 4 SMA Negeri 14 Medan Tahun Pembelajaran 2017/2018 termasuk baik $(76,, 25 \pm 10,83$ dan aktivitas siswa $(70,68)$

Hasil belajar siswa yang dibelajarkan menggunakan model pembelajaran Direct Instruction (DI) pada materi sistem peredaran darah manusia di kelas XI IPA 3 SMA Negeri 14 Medan Tahun Pembelajaran 2017/2018 masih kurang $(73,12 \pm 8,50)$, dan aktivitas siswa termasuk kategori kurang $(50,33)$

Hasil belajar dan aktivitas siswa pada materi Sistem Peredaran Darah Manusia berbeda jika dibelajarkan dengan menggunakan model pembelajaran Predict Observe Explain (POEdan Direct Instruction (DI), dimana baik hasil belajar maupun aktivitas siswa lebih tinggi dengan model POE dibandingkan dengan model DI.

\section{UCAPAN TERIMA KASIH}

Penulis mengucapkan terima kasih kepada staf dan para dosen FMIPA Pendidikan Biologi terutama dosen pembimbing saya Dr. Melva Silitonga, M.S. serta jajaran Kepala Sekolah dan Guru SMA Negeri 14 Medan juga teman-teman khususnya buat sahabat pendidikan biologi B 2013 yang banyak memberikan kesan yang luar biasa kepada penulis.

\section{DAFTAR PUSTAKA}

Kose, S., Billen, K. \& Ucak , E. (2010). Predictobserve-explain (POE) strategy as a diagnostic tool to determine pre service primary teachers misconseption on food synthesis of the plants and photosynthesis. Proceedings of the 6 th International
Conference on Education, July 8-10, Samos Island, Greece

Yip, D. Y. (1998). Teachers Misconseptions of the circulatory system. Journal of Biological education, 4(2) : 287-294

Trianto. 2009. Mendesain Model Pembelajaran Inovatif-Progresif: Konsep, Landasan, dan Implementasinya pada Kurikulum Tingkat Satuan Pendidikan (KTSP). Jakarta: Kencana

Djamarah, S.B. (2011). Psikologi Belajar. Jakarta : Rineka Cipta

Suharti, Syahrilfuhdin, Marhadi, H. (2016). Penerapan Model Pembelajaran Langsung Untuk Meningkatkan hasil belajar Matematika Siswa SDN 001 Sawah Baru. Riau : UNRI

Udayani KM, Kusmarityani NN, \& Mahadewi. 2016. Penerapan ModelPredict Observe Explain (POE) Untuk Meningkatkan Hasil Belajar Siswa. E-journal PGSD Universitas Pendidikan Ganesha, 4(1) : 1-10

Rahayu, S. (2012). Pengembangan Perangkat Pembelajaran Model POE Berbantuan Media "I am a Scientist". Innovative Journal of Curriculum and Educational Technology 2 (1): 1-12

Puspitasari. R, Lesmono.A.D, Prihandono. T. (2015). Pengaruh Model POE (Predict Observe Explain) disertai media audiovisual terhadap keterampilan kerja ilmiah dan hasil beljar siswa dalam pembelajaran IPA - Fisika di SMP. Jember: FKIP Jember, 3(1): 1-13

Firdos N.A.Y, Rudyatmi, \& Herlina L. 2013. Pengaruh Model POE dengan bantuan foto pada Materi Struktur dan Fungsi Tumbuhan. Unnes Journal of Biology Education 2(2) : 205-212 